\title{
ABBREVIATIONS AND SHORT TITLES
}

\author{
Commerce Commerce of Rhode Island, 1726-1800. Collections of the Mas- \\ sachusetts Historical Society. 7th Series., Nos. 9 and 10. Boston, \\ $1914,1915$. \\ Diary The Literary Diary of Ezra Stiles. Ed. Franklin B. Dexter. 3 vols. \\ New York, I90r. \\ Documents Documents Illustrative of the Slave Trade. Ed. Elizabeth Donnan. \\ 4 vols. Washington, D.c., 1930-1935. \\ Itineraries Extracts from the Itineraries and Other Miscellanies of Ezra Stiles, \\ D.D., LL.D., 1755-1794. Ed. Franklin B. Dexter. New Haven, \\ Conn., 1916. \\ NHS Newport Historical Society, Newport, Rhode Island \\ NM Newport Mercury \\ NYHS New-York Historical Society, New York, New York \\ PRO Public Record Office of Great Britain, London \\ RICR Records of the Colony of Rhode Island and Providence Plantations. \\ Ed. John Russell Bartlett. Io vols. Providence, 1862. \\ RIHS Rhode Island Historical Society, Providence, Rhode Island
}

\section{Editorial Note}

In order to preserve the integrity of the eighteenth-century manuscripts which have been quoted, original spelling has been retained throughout. For the same reason, conformity of citations has given way to exact replication of address. For example, letters to or from Godfrey and John Malbone will be cited as being sent or received by either Godfrey and John Malbone or $\mathrm{G}$ and J Malbone, depending on the way the names appear in the original document. 